\title{
The Energy Transition between profitability, participation and acceptance - considering the interests of project developers, residents, and environmentalists
}

\author{
Stephan Bosch ${ }^{1}$, Joachim Rathmann ${ }^{2}$, and Lucas Schwarz ${ }^{1}$ \\ ${ }^{1}$ Institute of Geography, University of Augsburg, 86159 Augsburg, Germany \\ ${ }^{2}$ Institute of Geography and Geology, University of Würzburg, 97074 Würzburg, Germany
}

Correspondence: Stephan Bosch (stephan.bosch@geo.uni-augsburg.de)

Received: 24 May 2019 - Revised: 5 August 2019 - Accepted: 7 August 2019 - Published: 15 August 2019

\begin{abstract}
The number of actors in the German Energy Transition as well as the planning complexity increases and new spatial implications emerge in contrast to the conventional energy system. In planning processes for Renewable Energy Technologies mostly economic approaches are chosen, but simultaneously the number of social conflicts related to wind power plants or solar energy plants is on an all-time high. The aim of the study is therefore to identify the essential parameters of a sustainable expansion of renewable energies from the diversity of potential influencing factors and to illustrate them using a regional case study and GIS. The analyses reveal the great regional assertiveness of photovoltaics, whereby wind energy can assert itself due to social parameters also at some locations. Beyond this, it is to be stated that renewable energies find themselves in intense economic and social competition for space, although the most compatible spatial solutions have not always been able to prevail so far. Nevertheless, the presented approach offers a sophisticated method to minimize the social conflicts that arise in the context of the energy system transformation.
\end{abstract}

\section{Introduction}

Since the beginning of the German Energy Transition debates about the system transformation focussed strongly on engineering perspectives (Blaschke et al., 2013). Especially the expansion of Renewable Energy Technologies (RET) is based on techno-economic approaches (Omitaomu et al., 2012). Zoellner et al. (2008) even claim that the focus of politics and industry lies on the economic feasibility for too long and social matters where completely excluded. Therefore, many local conflicts arose along planning processes, leading to a breach of trust between project planners and the local population. Especially Aitken (2010) criticises this techno-economic point of view and therefore calls for a critical reflection of this pro-renewable-energy attitude. Zoellner et al. (2008) even claim that the technological characteristics of RET can be neglected and the focus for planning processes should exclusively lay on negotiation processes between different actors. This approach is rather challenging as many new actors are involved in the energy system transformation. Thus, not only power supply companies but communities, middle-class companies, associations and private persons can take part in planning and operating local renewable energy plants (Gailing et al., 2013). The motives underlying these actors actions are therefore as diverse as they are contradictory and lead to a much greater socio-technical complexity in the development of renewable energy systems than was the case in the context of pure fossil-nuclear energy systems, where the major energy suppliers have made economic and rational decisions on the expansion of power plants as far as possible in accordance with the manageable entrepreneurial and social objectives of economic efficiency and security of supply (Bosch, 2018).

In view of the strong presence of techno-economic approaches in the expansion of renewable energies, there is a danger that social aspects will only be taken into account by the state to the extent that they do not impair the addressed expansion targets (Aitken, 2010). In this sense, the identification of suitable search areas for renewable energies would only appear to be open-ended. In fact, the spatial result would already have been determined at the beginning of the plan- 
ning phase. Political specifications and the spatial requirements derived from them thus coagulate into non-negotiable invariants, in complete contrast to the spatial-social barriers which, according to the political specifications, are intended to uncover the necessary location pattern (Cowell, 2010). Additionally, the careless use of GIS-tools is criticized as they pretend that social matters are diligently included in planning processes. In reality the analytic depth of the planning process is strongly determined by the political framework and therefore control lies within the distant political instances thus making social aspects computable and governable (Murdoch, 2000). To this end, the social sciences are instrumentalized, in order to solve the social blockades for energy policy ambitions (Shove, 1998). Even the right to co-determination must be regarded as problematic if it serves the sole cosmetic purpose of legitimising decisions already taken (Hildyard et al., 2001) because it manipulates the social according to the interests (Bulkeley et al., 2005) and decouples it from the national goals (Cowell, 2010). In order to achieve national targets the possibility of intervention of spatial planning instances is reduced in favour of effective top-down processes, as the example of Scandinavia shows (Liljenfeldt, 2015).

This form of planning, which can both ignore and integrate the local contexts according to the political guidelines, is the power base of higher-level energy planning (Demeritt, 2001). The visual expression of this power are the resulting maps, which cast the specifications of energy policy into spatialadministrative forms and reduce the heterogeneity of the subspaces to controllable categories, such as wind speed, global radiation, and biomass yield. Harvey (1996) has pointed out that such arbitrary spatial categorisations often emerge from a market-economy-capitalist logic in which few powerful actors exercise control over localised resources. The social brisance that results from this "environmental injustice" (KellyReif and Wing, 2016) endangers the sustainable expansion of RET in Germany.

How this expansion can be socially balanced and how it can be designed beyond a state target determinism is highly controversial, since the new diversity of actors has led to a variety of perspectives on what can be described as a sustainable expansion of renewable energies. This is not a disadvantage per se as it means a high degree of democratization (Raven et al., 2016) but it poses challenges for the economic practicability. Additionally, the complexity of planning processes is increased because of varying local contexts that are an inevitable part of the development of every RET project. Therefore, scientific approaches, defining a compatible expansion of RET and determining the most suitable technology for a given location are still lacking. This research gap shall be tackled as the majority of RET projects are planned in rural areas and residents and project planners need a common base of understanding of planning processes and principles in order to avoid social conflicts in context of the German Energy Transition.
Therefore, the aim of the study is to identify the essential parameters of a sustainable expansion of renewable energies from the diversity of potential influencing factors and to illustrate them based on a regional case study. But first and foremost the study has an inductive character, since a generally valid scheme for the compatible expansion of energy technologies is derived from the state of research. In a second step the developed scheme, which in the logic of geographic energy research should have a strong landscape-analytical reference, is applied in a deductive way and GIS-based to a region, with the aim of being able to analyse and visualise the spatial compatibility competition of different technologies. On the one hand, the question arises which form of energy is the most compatible option in a technological comparison for a selected space and the people living there. On the other hand, the absolute degree of compatibility of the most suitable technology is determined. These results can then be compared with the actual spatial distribution of renewable energies within the region to be investigated and conclusions can be drawn regarding the compatibility of past and future expansion.

\section{Methods and theoretical background}

The study's aim is to identify essential parameters for a compatible expansion of renewable energies and to illustrate those along a regional case study. Aitken's (2010) criticism is included as the study's parameters are not derived from national frameworks and social factors have been holistically included. Additionally, the study's parameters are strongly based on the logic of energy geographies (Calvert, 2016) and combine social science with a geographical approach (Sovacool, 2014). The study's aim is to develop a GIS tool for the comparison and visualization of spatially and socially compatible RET.

As the expansion of RET in the last years mostly failed because of social conflicts and a strong decrease of acceptance was noted (Bosch et al., 2016), social parameters were strongly focussed.

Since many studies have different approaches to the compatibility of RET expansion (e.g. Höfer et al., 2016) the essential parameters to be considered are derived from the scientific literature, operationalized and then processed in a GIS-supported analysis and visualized cartographically. The research area is the planning region Augsburg (Bavaria) in the South of Germany, where a high number of photovoltaic and biogas plants but only a little number of wind turbines was built in the last couple of years (cf. Fig. 1). The exact locations of the renewable energies are stored in the Energy Atlas of Bavaria (StMWi, 2019), so that on this basis and with the help of georeferencing, a new layer could be created and placed alongside the analyses.

The GIS-supported intersection of parameters of a compatible expansion requires a standardization of the respective 


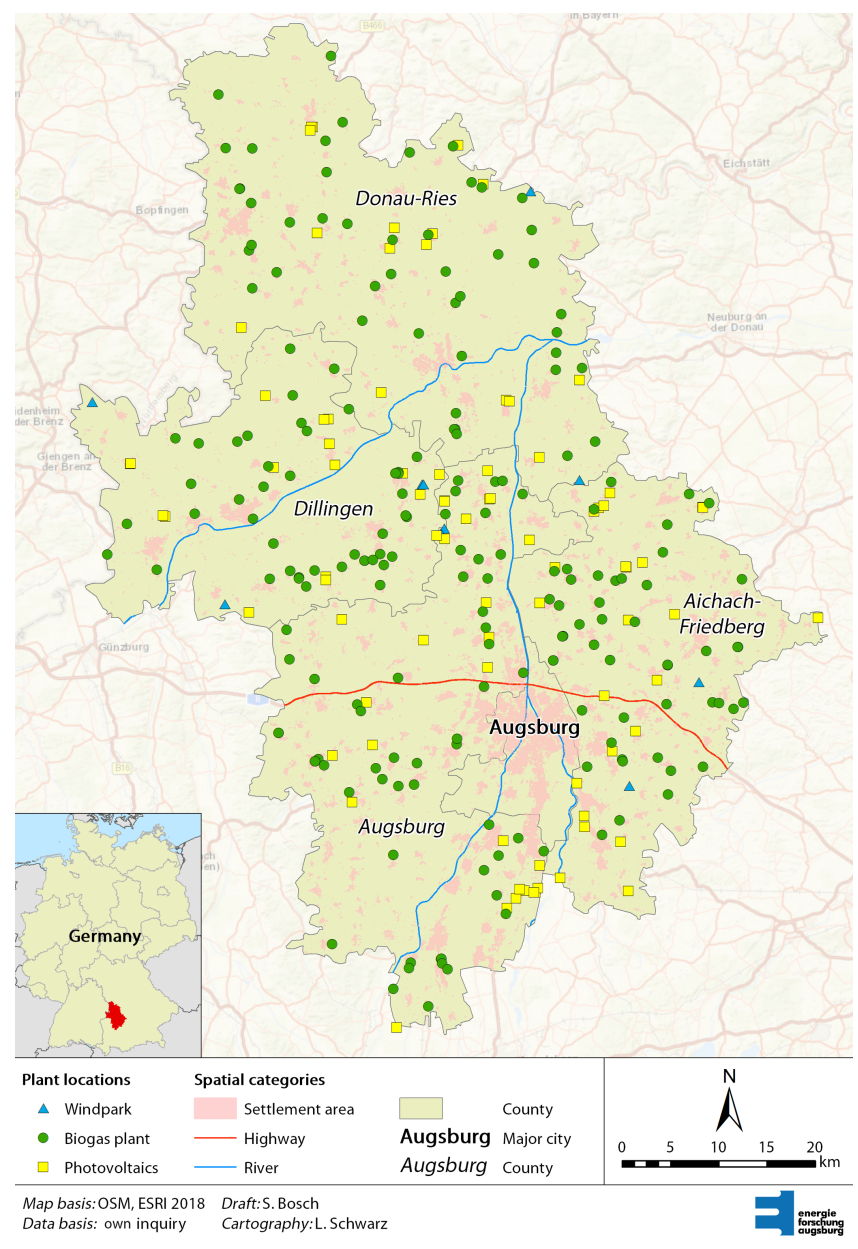

Figure 1. Spatial Distribution of RET in the Research Area.

parameter values. Through this, the spatial variability of the compatibility of renewable energies can be mapped. The degree of compatibility of an energy form is always determined on the basis of the sum of all parameters, whereby all factors are equally weighted and must always be seen in relation to the technological prerequisites of the energy forms considered in the study. As mostly wind and solar power plants are matters of conflicts in Germany's rural areas, bio energy plants were left out for the analysis.

The research area was split into raster cells with a spatial resolution of $1 \mathrm{~km}$. Finally, every grid is assigned a value containing the information about the most compatible RET and the degree of compatibility.

Due to the application of a GIS-supported procedure for the optimization of the expansion of renewable energies, the present study has a superficially planning-scientific character. Furthermore, the study takes up the current discussions of social science landscape research. In particular, it deals with the question to what extent social conventions shape the existing understanding of landscape as well as the reaction to interventions in it and how spatial and temporal modifica- tions can be recognized due to different individual and social constructions (Kühne, 2018). The theoretical foundation of the study is the "social gap" (Bell et al., 2005, 2013) as a part of "Energy Justice" research. Bell et al. (2005) define the "social gap" as a state that creates social groups that are disadvantaged by the expansion of RET. The present study aims at compensating this so called "energy underclass" (Bickerstaff et al., 2013) and creating an alternative planning approach that is more socially balanced during location decisions.

\section{State of research and operationalization of parameters}

The following literature overview that was used to identify the essential parameters for RET expansion, comprises mostly conflictive studies and studies that focus on planning processes and economic viability. Höfer et al. (2016) or Kabir et al. (2018) strongly focus on techno-economic parameters such as geophysical features (e.g. wind speed, solar radiation). Cowell (2010) emphasises that such approaches never cover all techno-economic factors and are therefore incomplete. Project planners are more interested in small scale constraints such as relief or quality of roads (SchallenbergRodríguez and Notario-del Pino, 2014).

Following Cowell (2010) and Höfer et al. (2016) the visual effect of landscape change is one of the main parameters for the sustainable expansion of RET and many studies focused on this aspect (cf. Soini et al., 2011; Pasqualetti, 2012; Kühne, 2018). The perspectives reach from a focus on physical objects in landscapes (Schöbel, 2012), over landscape ideals (Kirchhoff, 2014) to constructivist energy landscape research (Linke, 2018). Kirchhoff (2014) describes that the societal target of conserving the landscape appearance makes it impossible to build RET plants with a high aesthetic quality. The rejection of RET in order to preserve scenic landscapes is quite complex as it is based on emotions and symbolic meanings (Sijmons and Van Dorst, 2013). Especially the sense of homeland and the refusal of change is a major reason for the rejection of RET (Kühne, 2011). Additionally, RET are not perceived as elements of aesthetic landscapes (Kühne and Weber, 2016). As the perception of landscape depends on personal values (Palmas et al., 2015), van der Horst (2007) concludes that resistance to renewable energies in areas with a high-quality landscape is recruited from people who move their homes there for lifestyle reasons and have no connection whatsoever with the local traditional industries. The rural area here no longer secures the foundations of existence, but the social status of an individual, comfortable lifestyle (Blaschke et al., 2013). Although, not all different motives for the perception of landscape and refusal of RET can be captured, Schöbel (2012) and Kirchhoff (2014) demand a strong inclusion of landscape aesthetics in planning processes to minimize local planning conflicts. 
The political strategy for the expansion of RET includes the development of those mainly in burdened areas, such as areas along highways. Even the feed-in tariffs in such areas are higher and show the preferences of the German government for this strategy (BMJV, 2017). This focus is understandable as there are no or only little conflicts expectable (Zoellner et al., 2008). The connection between energy consumerism and the generation of energy is omnipresent for people living in industrial areas (van der Horst, 2007). Nonetheless, Nölting et al. (2011) note that people in Eastern Germany are sceptical when it comes to landscape changes, as they collectively experienced economic demise after the reunion of East and West Germany and the immediate experience of failure of major projects (Becker et al., 2012). This created a solid base for resistance against dramatic landscape change by RET. Even offshore wind energy is a matter of conflict although project planners hoped for the opposite (Devine-Wright and Howes, 2010; Meister, 2018). Bridge et al. (2018) stress that the aim should not be to avoid conflict and controversy. Rather, these phenomena are the expression of a vital democratic political negotiation process that constantly questions the structures of energy systems and controls the underlying decision-making processes. For this reason, the role of citizens' initiatives in planning processes must be taken up.

Blaschke et al. (2013) note a methodological difficulty in locating support or opposition towards RET, as it is based on personal values and environmental constructivism. Kühne and Weber (2016) point out that critical voices on the energy system transformation are predominantly represented by older conservative men. Younger people, on the other hand, are in a better position to come to terms with the newly emerging energy infrastructures. Therefore, the assessment of landscape quality or aesthetics is not only based on material elements but also on symbolic and emotional meanings (Bridge et al., 2013). Those phenomena are spatially limited, such as local support or opposition, as they rely on local circumstances and recruitment of locals (Bell et al., 2005). Van der Horst (2007) describes that the engagement of locals against proposed RET plants decreases with the spatial distance and adheres a "handicap of administrative geography". Warren et al. (2005) noticed the same phenomena. Van der Horst (2007) additionally mentions a "reversespatial-effect": Opposition of RET is stronger when the proposed site is closer, but as soon as the power plants are constructed, the support increases in the near proximity of the power plant. Both phenomena weaken with the distance from the power plant.

A basic strategy of project planers is to avoid ecologically valuable areas to correspond with political requirements (BfN, 2009; Job et al., 2016). The present study considered this by classifying such areas as less compatible, but a general exclusion was only done when it is technically not possible to build a RET plant in an area, e.g. in rivers or lakes.
Finally, spatial planning basis is often derived from GIS but as most of the current GIS-approaches only focus on distances and techno-economic factors (cf. Sunak et al., 2015; Höfer et al., 2016; Sunak and Madlener, 2017). Although these studies have attempted to improve the compatibility of the energy system transformation, important social factors, which are repeatedly discussed, have not been included in the analyses (Bosch and Schwarz, 2018). Therefore, this study is an approach to the increased complexity of RET planning and integration of social factors.

The essential social parameters were derived from the state of research: landscape aesthetics, landscape structure, citizens' initiatives, experience, participation, energy and climate concepts and social demographics. Based on those features a social raster was created that contains information about the social quality of a location in contrast to technological interference within a grid. As the spatial resolution on social parameters is greater than one grid, these values had been interpolated. In order to create the social raster, all parameters were spatially located, normalized and blended. The exact operationalization is explained in the following part.

\subsection{Landscape aesthetics and landscape structure}

Landscape aesthetics was determined using the index of touristic and landscape attractiveness (Einig et al., 2006). It divides Germany into five categories. The index on landscape aesthetics represents an additive combination of the following indicators at the district level, standardised on the federal value and aligned in the same way: (1) overnight stays in tourism, (2) water areas and coastlines, (3) degree of fragmentation, (4) relief energy and (5) degree of forest cover. According to this classification, the region under investigation belongs rather to the below-average aesthetic spaces, which was adopted in the analyses. The low scenic aesthetics have a positive effect on the probability of realisation of future energy projects, since changes in the landscape due to mechanisation are not so important. Additionally, landscape structure is important for the formation of regional identities and therefore need to be respected for the Energy Transition. In the research area three relevant units were identified: the nature park Augsburg Western Forests, the Geopark Ries and the Danube meadow. The compatibility rises with an increased distance to such units. The data basis for this was formed by the cadastre on the most beautiful geotopes in Bavaria (LfU, 2012) and the information on the spatial distribution of large protected areas in Germany (BfN, 2019). From this, a further layer was created and then blended with the layer for landscape aesthetics.

\subsection{Citizen's initiatives}

If a citizen's initiative is against the construction of RET, the social compatibility rises with distance and vice versa. In order to be able to create this layer, a time-consuming Internet 
search was used to identify and map all citizens' initiatives in the research area that either oppose the expansion of renewable energies or are committed to their expansion. In the present study it is assumed that if the citizens of a region have already had negative or positive experiences with renewable energies and have therefore founded an initiative against or in favour of them, this will have a negative or positive influence on the probability of realisation of future projects. With increasing spatial distance or proximity to the locations of the citizens' initiatives, their possible influences weaken or increase. This connection has been realized by spatial buffers around the citizens' initiatives and is thus part of the operationalisation of the social grid, which is intended to provide information on the probability of realisation of future energy projects.

\subsection{Experience}

The data basis of the Experience parameter is the regional cadastre of wind power and photovoltaic plants (StMWi, 2019). Thus, areas, where people already have experience with renewable energies can easily be mapped. Van der Horst (2007) and Kühne and Weber (2016) have pointed out that the acceptance of potential energy projects is higher if the residents already have previous experience with existing plants. Accordingly, acceptance decreases with increasing distance from these plants, as people have less and less opportunity to counter their fears and prejudices with concrete experience. The parameter experience represents as a layer exactly this spatial connection in the form of distance relations, i.e. with increasing spatial proximity to or distance from existing renewable energy plants the positive experiences strengthen or weaken. From a distance of $10 \mathrm{~km}$ to existing plants, no more positive experience can be assumed, so that buffers have been developed which reflect this fact in staggered fashion $(2.5,5,7.5,10,>10 \mathrm{~km})$.

\subsection{Participation and climate or energy concepts}

When operationalising the parameter of citizen participation, it is assumed that especially those facilities that contain participatory elements as citizen facilities and thus allow the voice and participation of local residents generate aboveaverage approval. Therefore, information on the forms of participation of existing facilities was obtained from the Energy Atlas of Bavaria (StMWi, 2019) and by means of further Internet research on the individual energy projects and combined into a new data basis. Due to the exemplary character of citizen facilities, a positive effect on the social compatibility of further projects in the direct vicinity of these democratically broadly legitimised facilities can be assumed. Conversely, in the vicinity of facilities initiated by supraregional investors and without civic participation, a lower social compatibility of future projects is expected. Both effects weaken with increasing spatial distance from the respective facilities, which in turn was depicted in staggered distance relationships as a spatial buffer $(2.5,5,7.5,10,>10 \mathrm{~km})$.

Furthermore, existing municipal and regional energy and climate protection concepts are seen as a kind of catalyst for the social integration of energy projects, since concerted strategies and education, which go hand in hand with a high flow of information to the citizens concerned, increase the understanding of planned and existing projects. On the other hand, a lack of concepts complicates the mediation of energy projects and has a negative impact on acceptance. In order to operationalise this parameter, all energy and climate protection concepts in the region were identified and recorded in their spatial effects, which can usually be easily defined on the basis of administrative units (e.g. municipal and regional energy concepts). The probability of realisation for future projects is greater within areas with an energy or climate protection concept than outside them.

\subsection{Demography}

The last element of the social grid is demography, taking into account gender and age. Kühne and Weber (2016) state that younger women tend to rate renewable energy positively, as they see it as progress towards civilization. In contrast, older males tend to dislike the spatial manifestations of the energy system transformation. Based on this finding, data from the Federal Statistical Office on age and gender were processed regionally (at district level) and combined into a layer (Statistisches Bundesamt, 2019). It should be noted here that this element of the social grid has a very limited half-life due to demographic developments and must be adapted again and again. This also applies to the parameters of citizens' initiatives, experience, participation and energy concepts. Nevertheless, within the framework of GIS-supported analyses, an attempt is being made for the first time to incorporate social constructivist parameters that are difficult to grasp.

After the individual operationalization of the parameters, data were normalized and blended so that they could be compared with each other. For this purpose, all social parameters were indexed on a scale of 1 to 5 , where 1 corresponds to a low and 5 to a high probability of realisation for future energy projects. For each grid cell (resolution $1 \mathrm{~km}$ ) in the study area, the average index value was calculated from all social parameters, whereby all parameters were weighted equally. The threshold values refer to the distance relationships explained in the context of operationalisation $(2.5,5,7.5,10$, $>10 \mathrm{~km}$ ). The spatial implications of the operationalization of social parameters is as follows (cf. Fig. 2): A strong regional difference is noted when visualizing the social compatibility in the research area. Usually, solar energy is socially more compatible than wind energy but, in some areas, it is the other way around. Especially the landscape structures (regional identity) are clearly visible.

As the state of research has shown the consideration of social aspects is not sufficient as RET plants are still eco- 


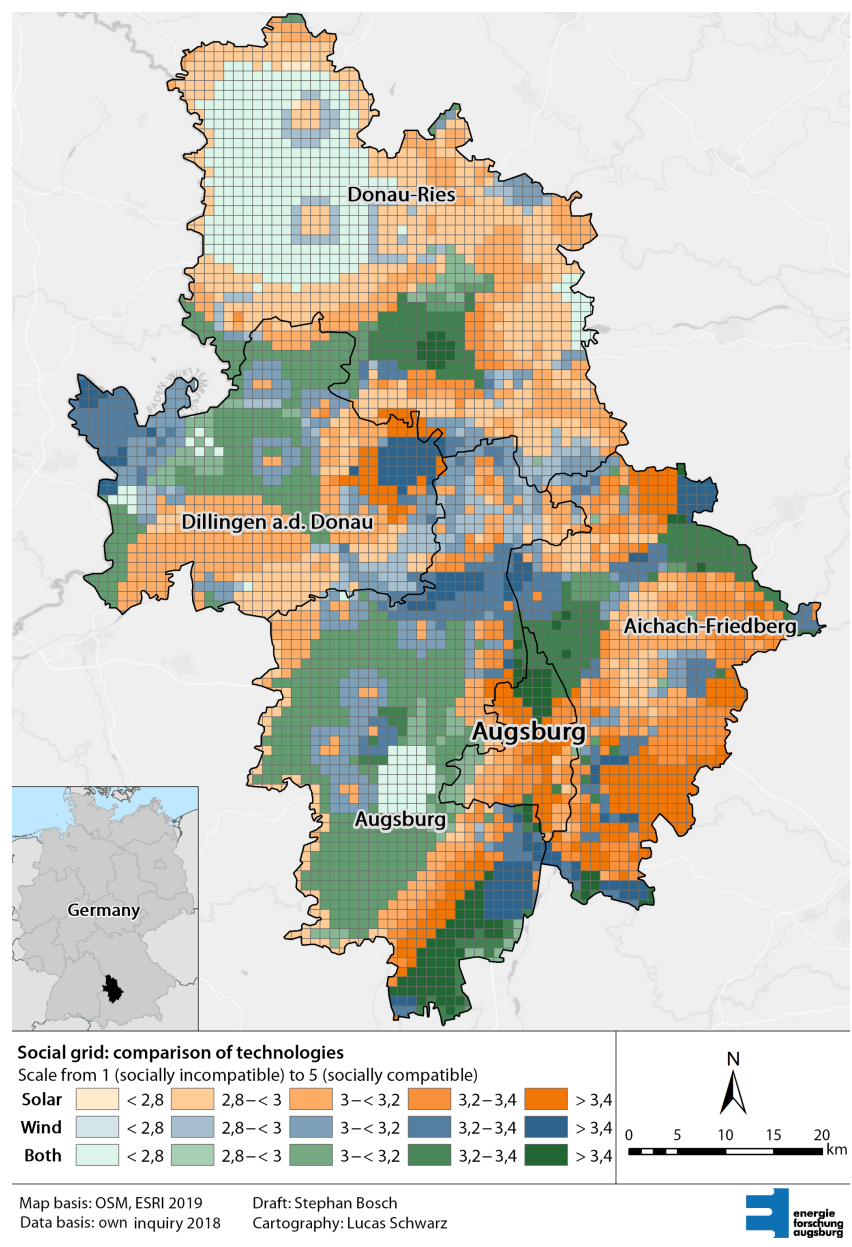

Figure 2. Socially compatible expansion of wind and solar energy.

nomic projects and need to be viable. For this reason, the social raster was completed by an economic raster that includes many factors that are important to project planners. Ecological factors were not individually treated but are part of factors such as landscape aesthetics, landscape structure, relief or land cover that are used in the social and economic raster. Additionally, the consideration of ecological factors is assured by the approval procedure.

The economic raster comprises the following factors: potential (average wind speed, solar radiation), access (quality and quantity of roads, distance to the highway), relief (slope), land cover (CorineLandCover-Data, cf. EEA, 2017) and population density. In order to estimate the economic viability of a location within a raster cell, all those factors were combined and defined on a scale from 1 (economically unviable) to 5 (economically highly viable). If only the potential is considered solar energy is always more economically viable in the whole research area. If all factors are included this state changes and wind energy is more viable, especially in the northern parts of the planning region (cf. Fig. 3).

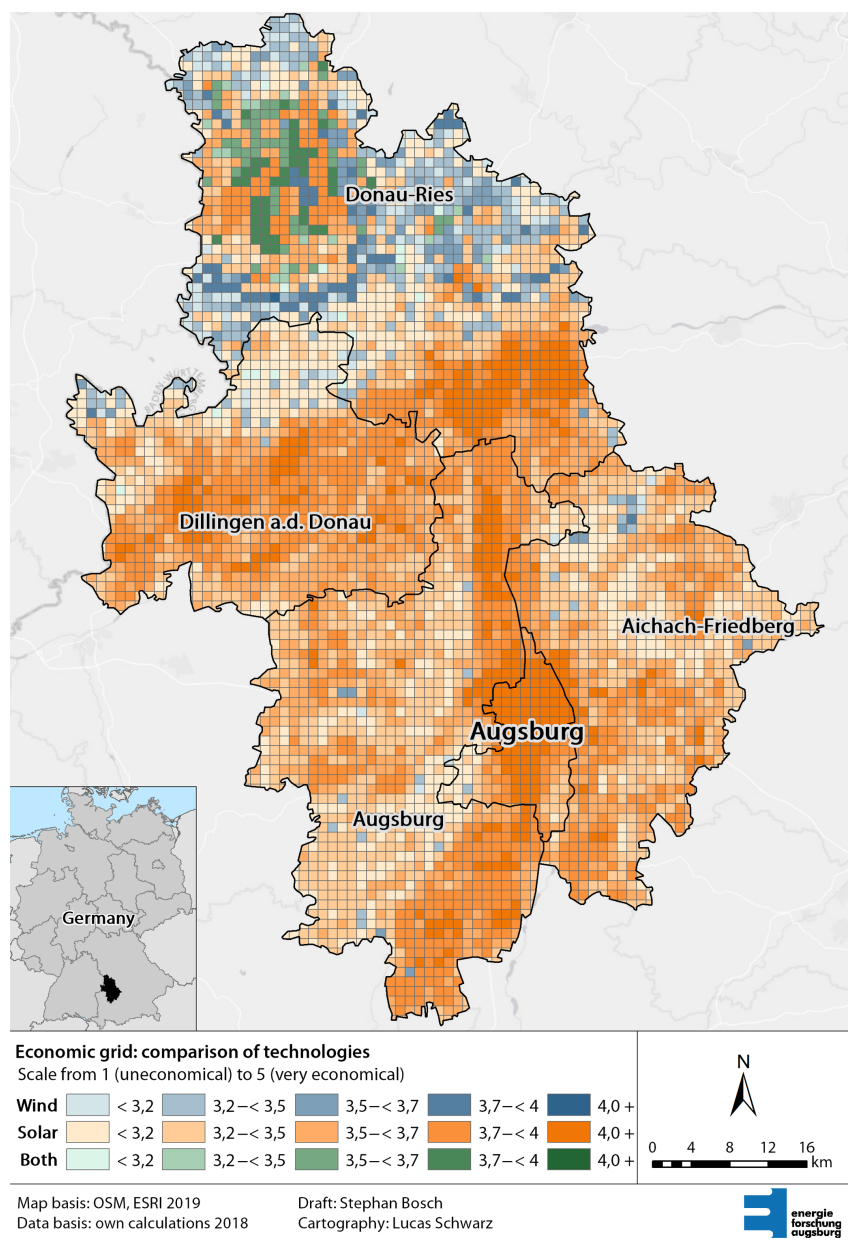

Figure 3. Economically compatible expansion of wind and solar energy.

\section{Results}

In a final step, the social and economic raster were superimposed and blended (social and economic factors equilibrated) in order to determine the spatial pattern of a comprehensively compatible expansion of renewable energies (cf. Fig. 4).The analyses reveal the great regional assertiveness of photovoltaics, whereby wind energy can assert itself due to social parameters also at some locations, particularly in the middle part of the study region, against the economically often better positioned photovoltaics. In contrast, wind energy loses locations in the northeast of the region to the more tolerable option of photovoltaics due to social parameters. When comparing the actual expansion of wind and photovoltaic plants with the map of the compatible expansion, it becomes apparent that in most parts of the region the strongly expanded photovoltaic is also the most compatible solution. In addition, photovoltaics have often been projected at locations where they are very suitable in absolute terms. Nevertheless, there are also plants that are located at rather unsuit- 


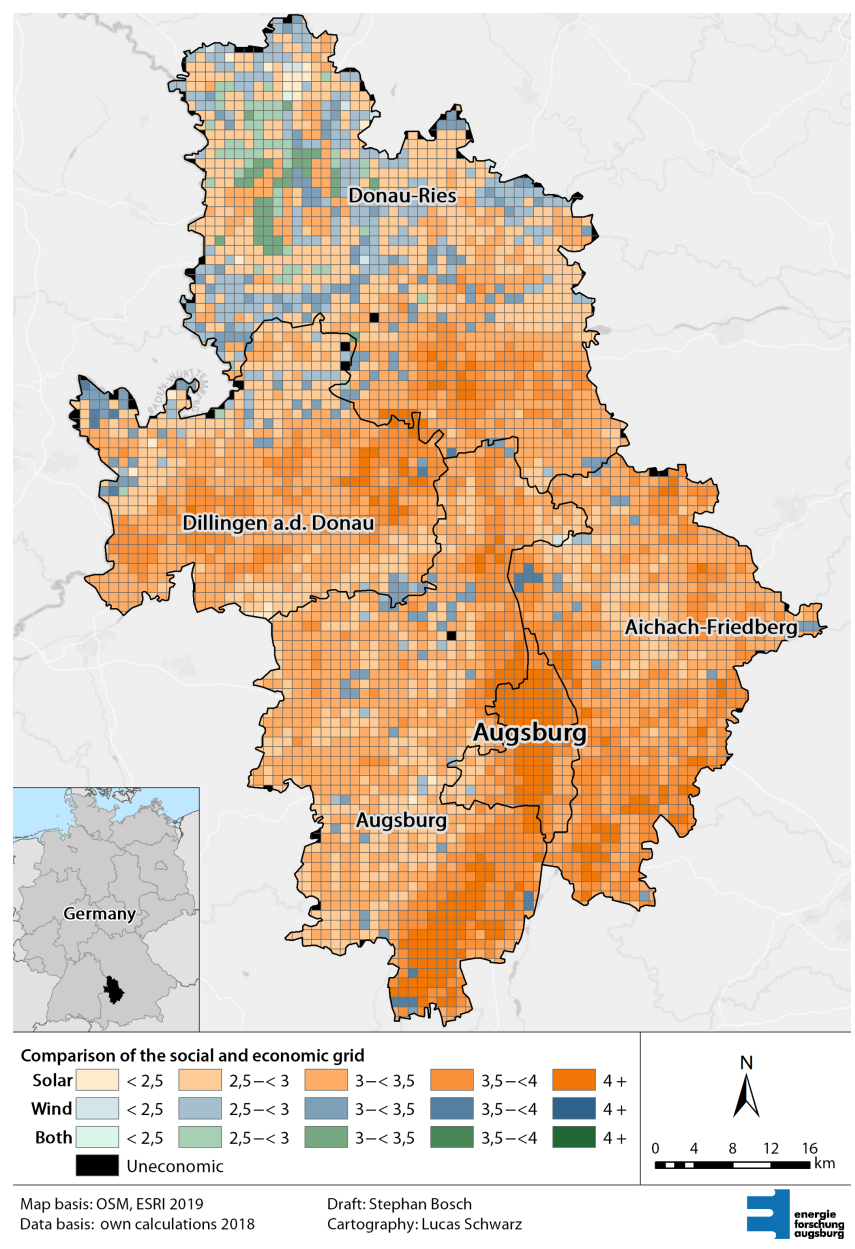

Figure 4. Compatible expansion of wind and solar energy.

able locations based on the parameters in the present study. In the context of further research, it should be clarified to what extent social conflicts have actually arisen at these locations. Wind energy is hardly developed in the region, which can also be seen as the result of its low compatibility. Nonetheless, efforts are taken to develop wind energy in the research area. For this reason, technology specific maps were developed to show in which area a technology can be considered compatible and were it should not be built due to economic or social reasons (cf. Fig. 5).

\section{Discussion}

\subsection{Transferability}

The transferability of the presented approach to other regions depends on the one hand on the availability of data and on the other hand on the prevailing importance and weighting of social and economic factors. Since the variability with regard to both aspects within Germany is low, a transferability and application of this approach to other parts of Ger-

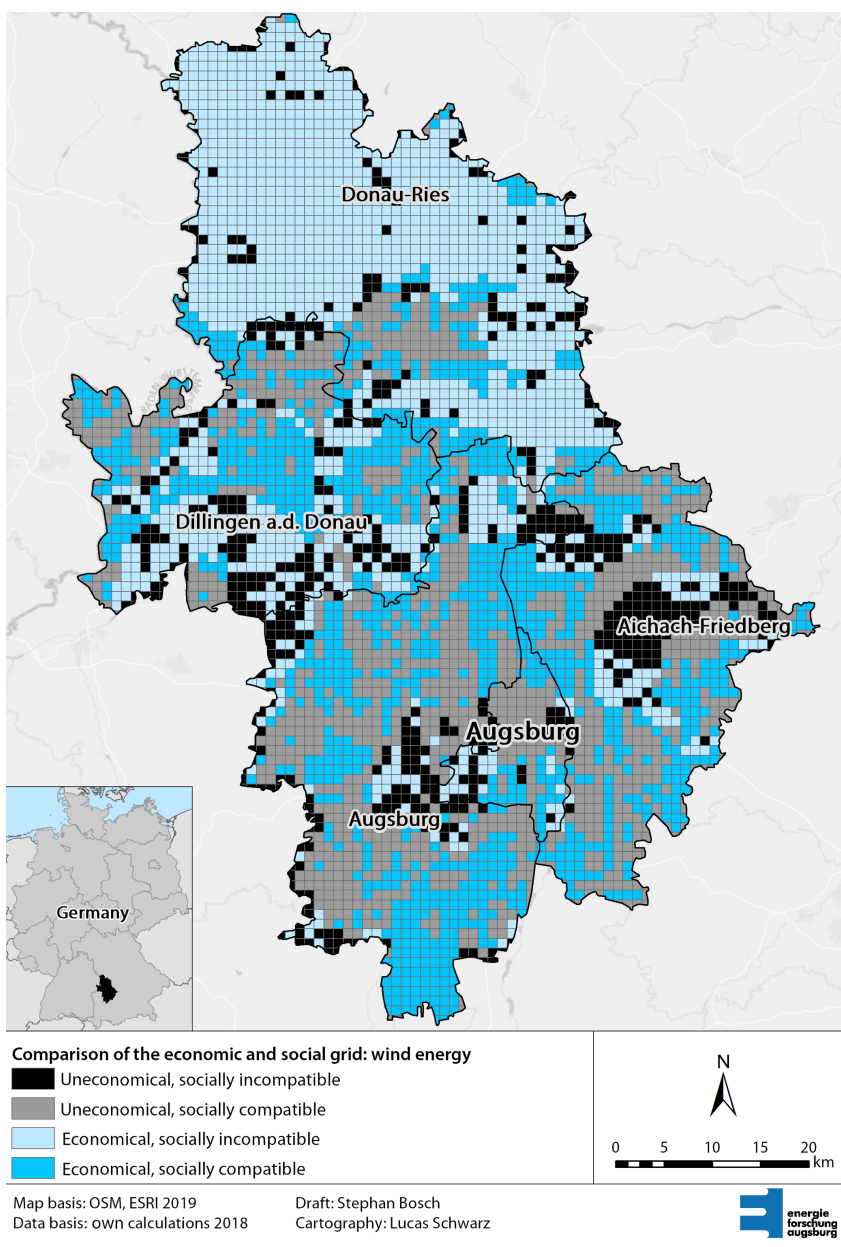

Figure 5. Compatible expansion of wind energy.

many can easily be done. However, due to the special attention Germany pays to the energy system transformation, it can be assumed that similarly high-quality data availability will not always be available in neighbouring or more distant regions. In other cultural areas, it can also be assumed that additional parameters should be included in GIS analyses. For example, Yenneti et al. (2016) were able to show that the large-scale expansion of photovoltaic open space plants in India has led to a gradual expropriation of the local population by the state. The poorer people living from agriculture were thus denied access to the land that has been their livelihood for decades. Baka (2013) speaks of "energy dispossessions". This phenomenon has also been observed in largescale wind farms (Cowell, 2010; Avila, 2018). The sociomaterial consequences of ecological modernisation for the local population are insufficiently taken into account. State energy policy has always given the doubtful impression that environmental protection and economic growth can go hand in hand on the basis of efficient technologies, competition and state intervention without social side effects (Levien, 2013). It is noteworthy that the controversial large-scale en- 
ergy projects, which are mainly to be found in the Global South, are not causally involved in the emergence of new power asymmetries and conflicts, but only bring to light and consolidate the already existing, far-reaching social inequalities and injustices (Avila, 2018). Therefore, according to Bradley and Hedrén (2014), the energy transformation taking place there misses its goal of sustainability precisely because the state is only concerned with modernizing the energy system, not with transforming the social structures behind it. These culturally specific characteristics in India's social structures would have to be taken into account within the framework of a compatible expansion of renewable energies in this region and therefore make the transferability of the approach presented here more difficult. Nevertheless, there is no doubt that this is possible within the framework of further research.

\subsection{Innerecological conflict}

GIS-supported analysis has shown that the degree of compatibility of the expansion of renewable energies strongly depends on the socially constructed protection status, which is only granted to certain areas (cf. BfN, 2019). In this respect, the methodology presented can certainly be adapted to changed ideas regarding the interplay between nature conservation and climate protection and would lead to new location patterns of a compatible expansion in this respect. In the present study, it was assumed that the suitability of an energy site would increase directly proportionally with increasing distance from natural areas worthy of protection, as recommended by Höfer et al. (2016) in their study. However, Job and Mayer (2012) emphasise that this form of nature conservation can also lead to high opportunity costs. For example, people living in protected areas miss out on considerable revenues by not being able to make use of existing resource utilisation opportunities due to their high conservation status. Palmas et al. (2015) see the inner-ecological contradiction between nature conservation and climate protection as the central conflict in the expansion of renewable energies, because in view of the current interpretation of nature conservation, the goals of energy system transformation are unattainable. A relaxation of the nature conservation-related spatial exclusion principle is therefore appropriate and could be justified by the fact that climate protection is of essential importance for ensuring ecosystem services. Bridge et al. (2013) recognise potential spatial synergy effects between climate protection and nature conservation, but emphasise that the idea of areas as untouched as possible is strongly present in society and could coagulate into robust planning and legally legitimised constructs. The result was a defensive attitude towards renewable energies that still found its conceptual expression in incremental negative planning (Schöbel, 2012). The problem here is that the restrictions on use are unbalanced. The "too much" of nature conservation-related restrictions in the wind energy sector, for example, is offset by "too little" in the context of photovoltaics and biomass (Palmas et al., 2015). Laggner et al. (2014) have pointed to the ecological problem of grassland upheaval as a result of indirect land-use changes due to the expansion of biogas production. However, there are no land-related regulations at the level of regional planning. In contrast, the ecological sensitivity of the expansion of wind energy is very high. Here, potential changes in the development plan also depend on the occurrence of field hamsters (IGR AG, 2015). Also avoidance effects on birds, which according to Kirchhoff (2014) have a low spatial relevance, are considered with very great care, and this completely in contrast to the highly relevant landscape aesthetic concerns. A new and technologically more balanced orientation of the relationship between nature conservation and climate protection would therefore be appropriate, whereby further research would have to analyse whether this would not only lead to a minimisation of land use conflicts, but also to the intensification of some spatial conflicts.

\subsection{Technological openness}

What is special about the approach presented is its technological openness, which can also be extended to include other technologies (e.g. biogas). Blaschke et al. (2013) criticise that the category "energy spaces" - which is to be understood as spatial, not technological definition - is not part of the basic instruments of spatial planning in almost any $\mathrm{Eu}-$ ropean country. Rather, area-based use regulations dominate, which attach particular importance to the expansion of wind energy, for example via priority areas. However, a high degree of technological openness would be possible, since at many points on the earth's surface it is in principle possible to generate regenerative energy both by means of wind power and by using solar or biomass plants. In view of technological progress, it is not so much the technology-specific, natural location factors that have a space-differentiating effect, but rather the cross-technology social framework conditions (Bosch et al., 2016). Consequently, the aim should not be to focus on the potential of a specific type of energy generation and only to push ahead with its optimization in the direction of cost reduction, emission reduction, or energy yield (Shove, 1998). Rather, it is appropriate to include the technical and social potential of the entire range of power generation plants, always in consideration of the local contexts in which they are to be expanded (Cowell, 2010). This perspective makes it possible to map the changing properties of technologies and the changing local contexts in the form of possible "geographical futures", thereby giving the energy system transformation the greatest possible spatial efficiency and acceptance (Bridge et al., 2013). Apart from this, it may also be useful to facilitate and specify the handling of technology-specific area-related use regulations, which are still of great importance in regional planning, by means of the approach presented. For example, the designation of priority, reserved and exclusion areas could be linked more closely to 
the holistic approach of a comprehensive impact assessment presented here, thus ensuring greater sustainability in the regional development of renewable energies.

\section{Conclusions}

Within the framework of the present study, a concept for the location pattern of a compatible expansion of wind and solar plants has been developed and illustrated by using a case study. The central parameters were derived from the scientific literature as well as from the currently existing planning and legal framework conditions. Among the most important social parameters are landscape aesthetics and landscape structures, the role of citizens' initiatives, the experience with existing energy projects, the possibilities of participation, the existence of energy or climate protection concepts as well as the socio-demographic characteristics of residents living near renewable energies. These parameters were weighted equally and thus united to form a social grid that reflects the spatial distribution of the probability of realisation of energy projects from a social perspective. Although social factors are of central importance, renewable energies can only be realistically projected where they are also economically viable. For this reason, an additional economic grid was developed that summarizes the central economic factors (natural potential, access, relief, land cover and population density) in a data set. Subsequently, the social grid was blended with the economic grid (social and economic factors equilibrated) in order to identify those locations that are socially and economically highly compatible with renewable energies.

The analyses reveal the great regional assertiveness of photovoltaics, whereby wind energy can assert itself due to social parameters also at some locations, particularly in the central part of the study area, against the economically often better positioned photovoltaics. In contrast, wind energy loses locations in the northeast of the region to the more tolerable option of photovoltaics due to social parameters. In further studies, other technologies should be integrated into GIS analyses in addition to wind and solar energy in order to illustrate spatial competition across the entire spectrum of renewable energies. Finally, reference should be made to the possibility of using the presented approach as a planning instrument within the framework of project development and regional planning, with the aim of giving greater precision to the project planning of plants and the designation of arearelated utilisation regulations.

Data availability. The datasets generated during the study are available at reasonable request sent to the corresponding author.

Author contributions. SB, JR, and LS conceived and designed the study; SB developed the GIS-based approach and investigated the literature; furthermore SB, JR, and LS wrote the paper. SB, JR, and LS read and approved the manuscript. SB revised the manuscript.

Competing interests. The authors declare that they have no conflict of interest.

Special issue statement. This article is part of the special issue "European Geosciences Union General Assembly 2019, EGU Division Energy, Resources \& Environment (ERE)". It is a result of the EGU General Assembly 2019, Vienna, Austria, 7-12 April 2019.

Financial support. This research has been supported by the German Research Foundation (DFG) (grant no. BO 4499/2-1).

Review statement. This paper was edited by Viktor Bruckman and reviewed by Johannes Schmidt and one anonymous referee.

\section{References}

Aitken, M.: Why we still don't understand the social aspects of wind power: A critique of key assumptions within the literature, Energ. Policy, 38, 1834-1841, https://doi.org/10.1016/j.enpol.2009.11.060, 2010.

Baka, J.: The Political Construction of Wasteland: Governmentality, Land Acquisition and Social Inequality in South India, Dev. Change, 44, 409-428, https://doi.org/10.1111/dech.12018, 2013.

Becker, S., Gailing, L., and Naumann, M.: Neue Energielandschaften - Neue Akteurslandschaften: Eine Bestandsaufnahme in Brandenburg, Rosa-Luxemburg-Stiftung, Berlin, 67 pp., 2012.

Bell, D., Gray, T., and Haggett, C.: The "Social Gap" in Wind Farm Siting Decisions: Explanations and Policy Responses, Environ. Polit., 14, 460-477, https://doi.org/10.1080/09644010500175833, 2005.

Bell, D., Gray, T., Haggett, C., and Swaffield, J.: Re-visiting the 'social gap': public opinion and relations of power in the local politics of wind energy, Environ. Polit., 22, 115-135, https://doi.org/10.1080/09644016.2013.755793, 2013.

Bickerstaff, K., Walker, G., and Bulkeley, H.: Energy Justice in a Changing Climate: Social Equity and Low-Carbon Energy, 1st Edn., Just Sustainabilities, Zed Books, London, 1234 pp., 2013.

Blaschke, T., Biberacher, M., Gadocha, S., and Schardinger, I.: "Energy landscapes": Meeting energy demands and human aspirations, Biomass Bioenerg., 55, 3-16, https://doi.org/10.1016/j.biombioe.2012.11.022, 2013.

Bosch, S.: Technologie- und Standortwahl beim Ausbau erneuerbarer Energien - Eine empirische Analyse zum unternehmerischen Verhalten von Anlagenbetreibern, uwf, Nachhaltigkeits Management Forum, 38, 1834, https://doi.org/10.1007/s00550-018-0477-8, 2018.

Bosch, S. and Schwarz, L.: Ein GIS-Planungstool für erneuerbare Energien - Integration sozialer Perspektiven, in: AGIT - Journal für Angewandte Geoinformatik, edited by: Strobl, J., Zagel, B., 
Griesebner, G., and Blaschke, T., 4, Wichmann-Verlag, Berlin, Offenbach a. Main, 92-101, 2018.

Bosch, S., Rathmann, J., and Simetsreiter, F.: Raumverträglicher Ausbau von erneuerbaren Energien - ein alternativer Standortplanungsansatz für eine nachhaltige Energiewende, Geogr. Helv., 71, 29-45, https://doi.org/10.5194/gh-71-29-2016, 2016.

Bradley, K. and Hedrén, J.: Utopian Thoguht in the Making of Green Futures, in: Green Utopianism, Perspectives, edited by: Bradley, K. and Hedrén, J. , Politics and Micro-Practices, Oxon, New York, 1-20, 2014.

Bridge, G., Bouzarovski, S., Bradshaw, M., and Eyre, N.: Geographies of energy transition: Space, place and the low-carbon economy, Energ. Policy, 53, 331-340, https://doi.org/10.1016/j.enpol.2012.10.066, 2013.

Bridge, G., Barr, S., Bouzarovski, S., Bradshaw, M., Brown, M., Bulkeley, H., and Walker, G.: Energy and Society, A Critical Perspective, Routledge, New York, 292 pp., 2018.

Bulkeley, H., Watson, M., Hudson, R., and Weaver, P.: Governing municipal waste: Towards a new analytical framework, J. Environ. Pol. Plan., 7, 1-23, https://doi.org/10.1080/15239080500251700, 2005.

BfN (Bundesamt für Naturschutz): Gesetz zur Neuregelung des Rechts des Naturschutzes und der Landschaftspflege (Bundesnaturschutzgesetz - BnatSchG), Bundesgesetzblatt Jahrgang 2009 Teil I Nr. 51, Bonn, 2009.

BfN (Bundesamt für Naturschutz): Gebietsschutz/Großschutzgebiete, available at: https://www.bfn.de/ themen/gebietsschutz-grossschutzgebiete.html, last access: 29 July 2019.

BMJV (Bundesministerium der Justiz und Verbraucherschutz): Gesetz für den Ausbau erneuerbarer Energien: Erneuerbare-Energien-Gesetz EEG, available at: https://www.gesetze-im-internet.de/eeg_2014/ (last access: 13 August 2019), 2017.

Calvert, K.: From "energy geography" to "energy geographies", Prog. Human Geogr., 40, 105-125, https://doi.org/10.1177/0309132514566343, 2016.

Cowell, R.: Wind power, landscape and strategic, spatial planning-The construction of "acceptable locations" in Wales, Land Use Policy, 27, 222-232, https://doi.org/10.1016/j.landusepol.2009.01.006, 2010.

Demeritt, D.: Scientific Forest Conservation and the Statistical Picturing of Nature's Limits in the Progressive-Era United States, Environ. Plan D, 19, 431-459, https://doi.org/10.1068/d294, 2001.

Devine-Wright, P. and Howes, Y.: Disruption to place attachment and the protection of restorative environments: A wind energy case study, J. Environ. Psychol., 30, 271-280, https://doi.org/10.1016/j.jenvp.2010.01.008, 2010.

Einig, K., Kawka, R., Lutter, H., Pick, D., Pütz, T., and Spangenberg, M.: Analytische Grundlagen der Leitbilder, in: Neue Leitbilder der Raumentwicklung in Deutschland: Informationen zur Raumentwicklung, edited by: BBR (Bundesamt für Bauwesen und Raumordnung), 11/12, Berlin, 621-636, 2006.

EEA (European Environmental Agency): Corine Land Cover, available at: https://land.copernicus.eu/user-corner/technical-library/ corine-land-cover-nomenclature-guidelines/docs/pdf/ CLC2018_Nomenclature_illustrated_guide_20170930.pdf (last access: 12 January 2019), 2017.
Gailing, L., Hüesker, F., Kern, K., and Röhring, A.: Die räumliche Gestaltung der Energiewende zwischen Zentralität und Dezentralität, Explorative Anwendung einer Forschungsheuristik, Erkner, 61 pp., 2013.

Harvey, D.: Justice, nature and the geography of difference, Blackwell Publishing, Malden (Massachusetts), Oxford, Victoria, 468 pp., 1996.

Hildyard, N., Hedge, P., Wolvekamp, P., and Reddy, S.: Pluralism, participation and power: joint forest management in India, in: Participation: The new tyranny?, edited by: Cooke, B. and Kothari, U., Zed Books, London, 56-71, 2001.

Höfer, T., Sunak, Y., Siddique, H., and Madlener, R.: Wind farm siting using a spatial Analytic Hierarchy Process approach: A case study of the Städteregion Aachen, Appl. Energ., 163, 222243, https://doi.org/10.1016/j.apenergy.2015.10.138, 2016.

IGR AG: Vorhabenbezogener Bebauungsplan "Windenergieanlagen", available at: https://www.herxheimweyher. de/fileadmin/HER/www.herxheim.de/Daten/Bebauungsplaene/ Herxheimweyher/Windenergieanlagen\T1\textbackslash\%

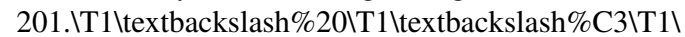
textbackslash\%84nderung/04_BPlan_Umweltbericht_150708_ Satzung.pdf (last access: 13 August 2019), 2015.

Job, H. and Mayer, M.: Forstwirtschaft versus Waldnaturschutz: Regionalwirtschaftliche Opportunitätskosten des Nationalparks Bayerischer Wald, Allg. Forst Jagdztg., 183, 129-144, 2012.

Job, H., Woltering, M., Warner, B., Heiland, S., Jedicke, E., Meyer, P., Nienaber, B., Plieninger, T., Pütz, M., Rannow, S., and von Ruschkowski, E.: Biodiversität und nachhaltige Landnutzung in Großschutzgebieten, Raumforsch. Raumordn., 74, 481-494, https://doi.org/10.1007/s13147-016-0440-5, 2016.

Kabir, E., Kumar, P., Kumar, S., Adelodun, A. A., and Kim, K.-H.: Solar energy: Potential and future prospects, Renew. Sustain. Energ. Rev., 82, 894-900, https://doi.org/10.1016/j.rser.2017.09.094, 2018.

Kelly-Reif, K. and Wing, S.: Urban-rural exploitation: An underappreciated dimension of environmental injustice, J. Rural Stud., 47, 350-358, https://doi.org/10.1016/j.jrurstud.2016.03.010, 2016.

Kirchhoff, T.: Energiewende und Landschaftsästhetik: Versachlichung ästhetischer Bewertungen von Energieanlagen durch Bezugnahme auf drei intersubjektive Landschaftsideale, Naturschutz und Landschaftsplanung, 46, 10-16, 2014.

Kühne, O.: Heimat und sozial nachhaltige Landschaftsentwicklung, Raumforsch. Raumordn., 69, 291-301, https://doi.org/10.1007/s13147-011-0108-0, 2011.

Kühne, O.: "Neue Landschaftskonflikte" - Überlegungen zu den physischen Manifestationen der Energiewende auf der Grundlage der Konflikttheorie Ralf Dahrendorfs, in: Bausteine der Energiewende, edited by: Kühne, O. and Weber, F., RaumFragen, Springer VS, Wiesbaden, Germany, 163-186, 2018.

Kühne, O. and Weber, F.: Zur sozialen Akzeptanz der Energiewende, uwf, Nachhaltigkeits Management Forum, 24, 207 213, https://doi.org/10.1007/s00550-016-0415-6, 2016.

Laggner, B., Orthen, N., Osterburg, B., and Röder, N.: Ist die zunehmende Biogasproduktion die alleinige Ursache für den Grünlandschwund in Deutschland? - eine Analyse von georeferenzierten Daten zur Landnutzung, Raumforsch. Raumordn., 72, 195-209, https://doi.org/10.1007/s13147-014-0278-7, 2014. 
Levien, M.: Regimes of Dispossession: From Steel Towns to Special Economic Zones, Dev. Change, 44, 2, 381-407, https://doi.org/10.1111/dech.12012, 2013.

LfU (Bayerisches Landesamt für Umwelt): Hundert Meisterwerke, Die schönsten Geotope Bayerns, AZ Druck und Datentechnik GmbH, Kempten, 288 pp., 2012.

Liljenfeldt, J.: Legitimacy and Efficiency in Planning Processes (How) Does Wind Power Change the Situation?, Eur. Plan. Stud., 23, 811-827, https://doi.org/10.1080/09654313.2014.979766, 2015.

Linke, S.: Ästhetik der neuen Energielandschaften - oder: "Was Schönheit ist, das weiß ich nicht", in: Bausteine der Energiewende, edited by: Kühne, O. and Weber, F., RaumFragen, Springer VS, Wiesbaden, Germany, 409-429, 2018.

Meister, T.: Der Ausbau von Offshore-Windparks in Deutschland aus einer Innovationsperspektive, Raumforsch. Raumordn., 76, 19-33, https://doi.org/10.1007/s13147-017-0510-3, 2018.

Murdoch, J.: Space Against Time: Competing Rationalities in Planning for Housing, Trans. Inst. Br. Geog., 25, 503-519, https://doi.org/10.1111/j.0020-2754.2000.00503.x, 2000.

Nölting, B., Thomas, M., and Land, R.: Energie im Osten. Die Energiewende als Chance für einen zukunftsfähigen Entwicklungspfad für Ostdeutschland, in: Neue Energie im Osten Gestaltung des Umbruchs. Perspektiven für eine zukunftsfähige sozial-ökologische Energiewende, edited by: Keppler, D., Nölting, B., and Schröder, C., Peter-Lang-Verlagsgruppe, Bern, 1535, 2011.

Omitaomu, O. A., Blevins, B. R., Jochem, W. C., Mays, G. T., Belles, R., Hadley, S. W., Harrison, T. J., Bhaduri, B. L., Neish, B. S., and Rose, A. N.: Adapting a GISbased multicriteria decision analysis approach for evaluating new power generating sites, Appl. Energ., 96, 292-301, https://doi.org/10.1016/j.apenergy.2011.11.087, 2012.

Palmas, C., Siewert, A., and Haaren, C. von: Exploring the decision-space for renewable energy generation to enhance spatial efficiency, Environ. Impact Asses., 52, 9-17, https://doi.org/10.1016/j.eiar.2014.06.005, 2015.

Pasqualetti, M. J.: Opposing Wind Energy Landscapes: A search for common cause, in: The New Geographies of Energy: Assessment and Analysis of Critical Landscapes, edited by: Zimmerer, K. S., Routledge, 206-216, 2012.

Raven, R., Kern, F., Verhees, B., and Smith, A.: Niche construction and empowerment through socio-political work, A meta-analysis of six low-carbon technology cases, Environmental Innovation and Societal Transitions, 18, 164-180, https://doi.org/10.1016/j.eist.2015.02.002, 2016.

Schallenberg-Rodríguez, J. and Notario-del Pino, J.: Evaluation of on-shore wind techno-economical potential in regions and islands, Appl. Energ., 124, 117-129, https://doi.org/10.1016/j.apenergy.2014.02.050, 2014.
Schöbel, S.: Windenergie und Landschaftsästhetik: Zur landschaftsgerechten Anordnung von Windfarmen, Jovis Verl., Berlin, 158 pp., 2012.

Shove, E.: Gaps, barriers and conceptual chasms: theories of technology transfer and energy in buildings, Energ. Policy, 26, 11051112, https://doi.org/10.1016/S0301-4215(98)00065-2, 1998.

Sijmons, D. and Van Dorst, M.: Strong feelings: Emotional landscape of wind turbines, in: Sustainable energy landscapes. Designing, Planning, and development, edited by: Stremke, S. and Van den Dobbelsteen, A., CRC Press, Boca Raton, London, New York, 45-70, 2013.

Soini, K., Pouta, E., Salmiovirta, M., Uusitalo, M., and Kivinen, T.: Local residents' perceptions of energy landscape: the case of transmission lines, Land Use Policy, 28, 294-305, https://doi.org/10.1016/j.landusepol.2010.06.009, 2011.

Sovacool, B. K.: What are we doing here? Analyzing fifteen years of energy scholarship and proposing a social science research agenda, Energ. Res. Soc. Sci., 1, 1-29, https://doi.org/10.1016/j.erss.2014.02.003, 2014.

Statistisches Bundesamt: Genesis-Online Datenbank, available at: https://www.genesis.destatis.de/genesis/online, last access: 28 January 2019.

StMWi (Bayerisches Ministerium für Wirtschaft, Landesentwicklung und Energie): Energie-Atlas Bayern, available at: https: //www.energieatlas.bayern.de/index.html, last access: 29 July 2019.

Sunak, Y. and Madlener, R.: The impact of wind farms on property values: A locally weighted hedonic pricing model, Pap. Reg. Sci., 96, 423-444, https://doi.org/10.1111/pirs.12197, 2017.

Sunak, Y., Höfer, T., Siddique, H., Madlener, R., and de Doncker, R. W.: A GIS-based Decision Support System for the Optimal Siting of Wind Farm Projects, E.ON, Energy Research Center Series, 7, 1-64, 2015.

van der Horst, D.: NIMBY or not? Exploring the relevance of location and the politics of voiced opinions in renewable energy siting controversies, Energ. Policy, 35, 2705-2714, https://doi.org/10.1016/j.enpol.2006.12.012, 2007.

Warren, C. R., Lumsden, C., O'Dowd, S., and Birnie, R. V.: "Green On Green": Public perceptions of wind power in Scotland and Ireland, J. Environ. Plann. Man., 48, 853-875, https://doi.org/10.1080/09640560500294376, 2005.

Yenneti, K., Day, R., and Golubchikov, O.: Spatial justice and the land politics of renewables: Dispossessing vulnerable communities through solar energy mega-projects, Geoforum, 76, 90-99, https://doi.org/10.1016/j.geoforum.2016.09.004, 2016.

Zoellner, J., Schweizer-Ries, P., and Wemheuer, C.: Public acceptance of renewable energies: Results from case studies in Germany, Energ. Policy, 36, 4136-4141, https://doi.org/10.1016/j.enpol.2008.06.026, 2008. 